\title{
IMPACT OF GST ON SPENDING BEHAVIOUR OF THE CONSUMERS
}

\author{
Dr. V. Chitra \\ Head, Department of Commerce (Honours), \\ Shri S.S. Shasun Jain College for Women, Chennai, India.
}

\begin{abstract}
Goods and Service Tax (GST) is a single tax on the supply of goods and services. The statutory tax rates under GST came into effect from $1^{\text {st }}$ July, 2017 which replaced all other applicable indirect taxes. The present study aims to analyse the relationship between income and spending behaviour and to measure the impact of GST on spending behaviour. The researcher has used Factor Analysis and ANOVA to test the hypotheses. The result showed that there is strong relationship between income and Electronic and Sport Equipments and no relationship between income and Wheat, rice, clothing, hair oil, soap, tooth paste, cosmetics, dry fruits, tobacco, fast food, internet connection, newspapers and magazines, fruits and vegetables, entertainment, vehicle maintenance and foot wares. The study also found that impact of GST is more on essential items than comfort and superfluous items.
\end{abstract}

Key word: GST, Spending Behaviour, Essential Commodities.

Cite this Article: Dr. V. Chitra, Impact of GST on Spending Behaviour of the Consumers, International Journal of Management, 10 (4), 2019, pp. 97-103.

http://iaeme.com/Home/issue/IJM?Volume=10\&Issue=4

\section{INTRODUCTION}

Goods and Service Tax (GST) is a single tax on the supply of goods and services. The statutory tax rates under GST came into effect from $1^{\text {st }}$ July, 2017 which replaced all other applicable indirect taxes. Some products and goods are taxed more while some others are cheaper. At present, the financial transaction and services which attracted service tax previously also replaced by GST. GST is a single tax on the supply of goods and services. A two-rate structure is being adopted. It means lower rate for necessary items and goods of basic importance and a standard rate for goods in general. There will also be a special rate for precious metals and a list of exempted items. It is a destination based tax which is levied only on value addition at each stage because credits of input taxes paid at procurement of inputs will be available. Thus, the final consumer will bear only the GST charged by the last dealer in the supply chain, with set-off benefits at all the previous stages.

\subsection{Benefits of GST}

- Overall reduction in prices of goods for consumers

- Reduction in Multiplicity of taxes, cascading and double taxation 
- Common national market and Uniform rate of tax

- Broader tax base and decrease in black transactions

- Non invasive electronic tax compliance system

\subsection{Types of GST in India}

- CGST - leviable on the supply made by a registered person within a country

- SGST/UTGST- leviable on the supply made by a registered person within a State/Union Territory

- IGST- leviable on import or inter-state supply of goods and services. IGST is equal to sum total of CGST and SGST/UTGST.

\subsection{Tax rate under GST}

It is not feasible to levy same rate of tax as there is wide socio-economic gap existing among the people of India. Therefore, Government has levied different tax rates for different class of items. Accordingly, four slabs fixed for GST rates - 5\%, 12\%, 18\% and $28 \%$.

1.1 Table showing GST rates applicable for various items

\begin{tabular}{|c|c|c|c|c|}
\hline $\begin{array}{c}\text { Exempted items } \\
\text { under GST }\end{array}$ & Items under 5\% & $\begin{array}{c}\text { Items under } \\
\mathbf{1 2 \%}\end{array}$ & $\begin{array}{c}\text { Items under } \\
\mathbf{1 8 \%}\end{array}$ & $\begin{array}{c}\text { Items under } \\
\mathbf{2 8 \%}\end{array}$ \\
\hline $\begin{array}{c}\text { Milk, buttermilk, } \\
\text { egg, curd, fresh } \\
\text { vegetables and } \\
\text { fruits, unbranded } \\
\text { flour, unbranded } \\
\text { wheat and rice, } \\
\text { Puja items. }\end{array}$ & $\begin{array}{c}\text { Frozen Vegetables and } \\
\text { fruits, branded wheat } \\
\text { and rice, branded flour, } \\
\text { hand-made safety } \\
\text { matches, cotton, cotton } \\
\text { fabrics, Footwear below }\end{array}$ & $\begin{array}{c}\text { Butter, Cheese, } \\
\text { Dry fruits, } \\
\text { mobile phones, } \\
\text { ayurvedic } \\
\text { products }\end{array}$ & $\begin{array}{c}\text { Biscuits, } \\
\text { footwear } \\
\text { exceeding Rs. } \\
500, \text { man- } \\
\text { made fibre, } \\
\text { hair oil, soap, } \\
\text { toothpaste }\end{array}$ & $\begin{array}{c}\text { LED TV, AC, } \\
\text { Cars, tobacco } \\
\text { products, } \\
\text { cement }\end{array}$ \\
& Rs.500 & & & \\
\hline
\end{tabular}

\subsection{Statement of the problem}

GST is a single tax on the supply of goods and services. It includes central excise duty, service tax additional duties of customers at the central level, VAT, central sales tax, entertainment tax, luxury tax, and other surcharge on supply of goods and services. The GST is to replace all these taxes with single comprehensive tax, bringing it all under single umbrella. GST may lower prices for regular household items. However, lifestyle choices of people will determine whether their outflows will grow or decline in the coming months with the effect of GST. People of our Country are very concern about this issue as their interests are at stake. The increasing attention on GST has called upon researchers to explore it in order to provide an insight into this issue. Therefore, this study focuses on determining the relationship between GST and spending behaviour of the consumers. This paper will throw light on tax rates under GST and also the impact of GST on spending behaviour.

\section{LITERATURE REVIEW}

R. Vasanthagopal (2011) in his topic "GST in India: A Big Leap in the Indirect Taxation System" concluded that switchover to a 'flawless' GST would be a big leap in the indirect taxation system and also give a new impetus to India's economic change. It is also noted that, more than 140 countries have introduced GST in some form to other and is fast becoming the preferred form of indirect tax in the Asia Pacific region. 
Nitin Kumar (2014) in his title "Goods and Service Tax- A Way Forward" concluded that implementation of GST in India helps in removing economic distortion by current indirect tax system and expected to encourage unbiased tax structure which is indifferent to geographical structure.

Shefali Dani S (2016) made an attempt to understand why the proposed GST regime may hamper the growth and development of the country. He pointed out that the proposed GST regime is a half hearted attempt to rationalize indirect tax structure. Further, the government should study the GST regime set up by various countries and also their fallouts before implementing in our country.

Shafie Mohamed Zabri (2016), investigated the level of understanding of GST and also examined the relationship between the understanding of GST and spending behavior among consumers in Batu Pahat, Johor, Malaysia. The result shows that the level of understanding towards GST among consumers in Batu Pahat is at moderate level. Besides, significant findings showed that changes in spending behavior among consumers in this study after the implementation of GST. It was also found that there was no significant relationship between the level of understanding of GST and spending behavior among consumers

Subhamoy Banik and Arundhuti Das (2017) opined that the economy is slowing down due to unplanned implementation of GST. Thus, the disruptions may have accelerated the decline. The only possible remedy for this disruption is to make the transition to GST simpler.

Prof.Pooja.S.Kawle and Prof.Yogesh.L.Aher (2017) concluded that a single tax will help to maintain simplicity and transparency by treating all goods and services equal without giving a special treatment to some types of goods and services. It will reduce the litigation on classification of issues. It is also said that implementation of GST in Indian framework will lead to commercial benefits which VAT has not given and hence it would essentially lead to economic development. GST may assure the possibility of overall gain for industry, trade, agriculture and also to central and state government. Now Indian consumer need to have professionalism to acknowledge the GST

Gupta (2017) stated that once GST is implemented, most of the challenges of the current indirect tax regime will be a story of the past. India will become a single market where goods can move freely across state borders, compliance will be easier, and costs of daily goods will reduce.

Dr. Yogesh Kailashchandra Agrawal (2017) aims to explain the mechanism of GST and its effects on Indian Economy. He highlighted the positive and negative impact of GST in Indian Economy and explained the working mechanism of GST in India. He concluded that GST is at the infant stage in India which will take some time to experience its effects on Indian Economy.

Dash (2017) studied the positive and negative impact of GST on Indian Economy. He stated that implementation of GST impacts a nation both positively and negatively. Ignoring negative aspects, positive aspects can be taken into consideration. In order to measure the impact of GST, we need to communicate more and more about the system. It can be a good way of reducing the black money and good effort by the government of India after the demonetization of money in 2016.

\subsection{Objective of the study}

- To throw light on tax rates for goods under GST

- To analyse the relationship between income and spending behaviour of consumers

- To measure the impact of GST on spending behaviour of the consumers

\subsection{Hypothesis}

Ho 1: There is no relationship between Income and spending behaviour of consumers 
Ho. 2: The factors of spending behaviour of consumers do not differ significantly.

\section{RESEARCH METHODOLOGY}

\subsection{Research design and sample size}

A total of 120 consumers were approached in South Chennai, Tamilnadu, India to distribute the questionnaire for the purpose of collecting primary data. Out of which 114 questionnaires were returned by the consumers but the researcher has selected only 100 questionnaires which were found usable. So sample size for the study is 100. Statistical tools like Factor Analysis and ANOVA are used to test the Hypotheses of the study.

\subsection{Area of the study and sample unit}

The survey is conducted in South Chennai to understand the impact of GST on spending behaviour of the consumers. The sample units are consumers who spends amount towards purchase of various commodities to fulfil their needs.

\subsection{Analysis and Interpretation:}

The study found that $44 \%$ of the respondents belong to the age group of $20-40$ yrs. Majority $(52 \%)$ of the respondents are female and $51 \%$ of the respondents are undergraduates and are earning above Rs.40,000 per month.

4.1 Table showing relationship between income and spending behaviour of the consumers on account of GST.

\begin{tabular}{|c|c|c|c|c|c|c|c|}
\hline & \multicolumn{6}{|c|}{ ANOVA } & \multirow[b]{2}{*}{ Inference } \\
\hline S.NO & $\begin{array}{c}\text { Effect of } \\
\text { GST on } \\
\text { Spending } \\
\text { behaviour } \\
\end{array}$ & $\begin{array}{c}\text { Sum of } \\
\text { Squares }\end{array}$ & df & $\begin{array}{c}\text { Mean } \\
\text { Square }\end{array}$ & $\mathbf{F}$ & Sig. & \\
\hline 1 & Entertainment & .696 & 2 & .348 & .429 & .652 & insignificant \\
\hline 2 & $\begin{array}{l}\text { Electronic } \\
\text { items }\end{array}$ & 4.760 & 2 & 2.380 & 3.916 & .023 & Significant \\
\hline 3 & Cosmetics & 2.680 & 2 & 1.340 & 2.567 & .082 & Insignificant \\
\hline 4 & $\begin{array}{l}\text { Tobacco } \\
\text { products }\end{array}$ & 2.345 & 2 & 1.172 & 1.618 & .204 & Insignificant \\
\hline 5 & $\begin{array}{l}\text { Newspapers } \\
\text { and } \\
\text { Magazines }\end{array}$ & 3.051 & 2 & 1.525 & 2.656 & .075 & Insignificant \\
\hline 6 & Fast Food & .031 & 2 & .016 & .023 & .977 & Insignificant \\
\hline 7 & Footwear & 3.970 & 2 & 1.985 & 2.450 & .092 & Insignificant \\
\hline 8 & $\begin{array}{l}\text { Internet/ } \\
\text { broadband } \\
\text { connection }\end{array}$ & 2.927 & 2 & 1.464 & 2.238 & .112 & insignificant \\
\hline 9 & $\begin{array}{l}\text { Sport } \\
\text { equipment }\end{array}$ & 5.554 & 2 & 2.777 & 3.888 & .024 & Significant \\
\hline 10 & Stationery & 2.509 & 2 & 1.255 & 1.822 & .167 & Insignificant \\
\hline 11 & $\begin{array}{l}\text { Vehicle } \\
\text { maintenance }\end{array}$ & .395 & 2 & .198 & .326 & .723 & Insignificant \\
\hline 12 & $\begin{array}{l}\text { Fruits and } \\
\text { vegetables }\end{array}$ & 3.180 & 2 & 1.590 & 2.164 & .120 & Insignificant \\
\hline 13 & Clothing & 3.997 & 2 & 1.999 & 2.781 & .067 & Insignificant \\
\hline 14 & $\begin{array}{l}\text { Wheat and } \\
\text { rice }\end{array}$ & 2.265 & 2 & 1.133 & 1.642 & .199 & Insignificant \\
\hline 15 & Dry fruits & 1.217 & 2 & .609 & .679 & .509 & Insignificant \\
\hline 16 & Biscuits & .085 & 2 & .043 & .077 & .926 & Insignificant \\
\hline
\end{tabular}




\begin{tabular}{|c|l|c|c|c|c|c|c|}
\hline 17 & $\begin{array}{l}\text { Hair oil, soap } \\
\text { and } \\
\text { toothpaste }\end{array}$ & 1.857 & 2 & .928 & 1.545 & .219 & Insignificant \\
\hline
\end{tabular}

Source: Computed Data

From the above table it is found that $p$ value for Electronic and Sports Equipments are 0.023 and 0.024 respectively which is less than the table value 0.05 . Hence null hypothesis is rejected at $5 \%$ level of significance only for these two items. The study proves that spending behaviour of the respondents is highly dependent on their income level. However for all other items, null hypothesis is accepted at 5\% level of significance and proved that there is no relationship between spending behaviour of the consumers and their income level.

\subsection{Factor Analysis}

The researcher has identified 17 factors to measure the impact of GST on spending behaviour of the consumers using Varimax Rotation Method and the following is the result of variable loading.

Table showing KMO and Bartlett's Test for Sampling Adequacy and Sphericity

\begin{tabular}{|c|c|}
\hline $\begin{array}{ll}\text { Kaiser-Meyer-Olkin Measure of Sampling Adequacy. } & \text { Approx. Chi-Square } \\
\text { Bartlett'sTestof Sphericity } & \text { df } \\
& \text { Sig. }\end{array}$ & $\begin{array}{l}837 \\
1206.357 \\
136 \\
.000\end{array}$ \\
\hline
\end{tabular}

From the above table, Kaiser-Meyer Value is 0.837 which is greater than 0.75 . It is concluded that the measure of sampling adequacy is good for factor analysis.

4.3 Table showing Total Variance

\begin{tabular}{|c|c|c|c|c|c|c|}
\hline \multirow{2}{*}{ Component } & \multicolumn{3}{|c|}{ Initial Eigen values } & \multicolumn{3}{c|}{$\begin{array}{c}\text { Rotation Sums of Squared } \\
\text { Loadings }\end{array}$} \\
\cline { 2 - 7 } & Total & $\begin{array}{c}\text { \% of } \\
\text { Variance }\end{array}$ & Cumulative \% & Total & $\begin{array}{c}\text { \% of } \\
\text { Variance }\end{array}$ & Cumulative \% \\
\hline 1 & 8.286 & 48.738 & 48.738 & 6.725 & 39.557 & 39.557 \\
\hline 2 & 1.574 & 9.259 & 57.998 & 2.534 & 14.904 & 54.460 \\
\hline 3 & 1.476 & 8.680 & 66.678 & 2.077 & 12.218 & 66.678 \\
\hline 4 & .932 & 5.482 & 72.160 & & & \\
\hline 5 & .784 & 4.613 & 76.774 & & & \\
\hline 6 & .706 & 4.151 & 80.925 & & & \\
\hline 7 & .665 & 3.912 & 84.837 & & & \\
\hline 8 & .481 & 2.830 & 87.667 & & & \\
\hline 9 & .461 & 2.712 & 90.379 & & & \\
\hline 10 & .357 & 2.097 & 92.477 & & & \\
\hline 11 & .266 & 1.568 & 94.044 & & & \\
\hline 12 & .265 & 1.557 & 95.601 & & & \\
\hline 13 & .211 & 1.241 & 96.842 & & & \\
\hline 14 & .174 & 1.021 & 97.863 & & & \\
\hline 15 & .159 & .935 & 98.797 & & & \\
\hline 16 & .120 & .708 & 99.505 & & & \\
\hline 17 & .084 & .495 & 100.000 & & & \\
\hline
\end{tabular}


Source: Computed Data

From the above table, it is clear that out of 17 variables only 3 components are extracted using Principal Component Extraction Method. First Component explains 39.56\% of Total Variance, Second Component explains 14.90\% and Third Component 3 explains 12.22\%

4.4 Table showing Variable loading

\begin{tabular}{|l|c|c|c|}
\hline \multicolumn{4}{|c|}{ Rotated Component Matrix } \\
\hline & \multicolumn{3}{|c|}{ Component } \\
\hline & $\mathbf{1}$ & $\mathbf{2}$ & $\mathbf{3}$ \\
\hline Fruits and vegetables & .826 & & \\
\hline Biscuits & .770 & & \\
\hline $\begin{array}{l}\text { Hair oil, soap and } \\
\text { toothpaste }\end{array}$ & .756 & & \\
\hline Wheat and rice & .752 & & \\
\hline Dry fruits & .746 & & \\
\hline Stationery & .741 & & \\
\hline Footwear & .727 & & \\
\hline Vehicle maintenance & .707 & & \\
\hline Clothing & .693 & & \\
\hline Electronic items & .666 & & \\
\hline Cosmetics & .645 & & \\
\hline Entertainment & .594 & & \\
\hline $\begin{array}{l}\text { Newspapers and } \\
\text { Magazines }\end{array}$ & & .829 & \\
\hline Sport equipment & & .686 & \\
\hline $\begin{array}{l}\text { Internet/ broadband } \\
\text { connection }\end{array}$ & & .617 & \\
\hline Tobacco products & & & .868 \\
\hline Fast Food & & & .642 \\
\hline $\begin{array}{l}\text { Extraction Method: Principal Component Analysis. } \\
\text { Rotation Method: Varimax with Kaiser Normalization. }\end{array}$ \\
\hline a. Rotation converged in 8 iterations. & \\
\hline
\end{tabular}

\section{Source: Computed Data}

From the above it is clear that the first factor consists of 12 variables which is named as 'Essential items; the second factor consists of 3 variables named as 'Comfort items' and the third factor consists of 2 items named as 'Superfluous items'.

\section{SUGGESTION}

Indian Government authorities can reduce the GST rates applicable to essential commodities to help the consumers to spend more on essential commodities as the impact of GST is more on essential items.

\section{CONCLUSION}

GST is designed in such a way to generate good amount of revenue for both central as well as state government. Moreover, collection of indirect taxes benefits both government and people of India. But GST has negative impact on spending behaviour of the consumers towards the essential commodities. It is essential on the part of the govt. to reconsider the tax rates in such a way that it does not affect the consumers of essential commodities largely. 


\section{REFERENCES}

[1] Dash, "Positive and Negative Impact of GST on Indian Economy", International Journal of Management and Applied Science, Volume 3, Issue 5, 2017.pp 158 - 160.

[2] Dr. R. Vasanthagopal, 'GST in India: A Big Leap in the Indirect Taxation System' International Journal of Trade, Economics and Finance, Vol. 2, No. 2,2011, pp 144-146

[3] Dr. Yogesh Kailashchandra Agrawal, "Goods and Services Tax and Its Impact on Indian Economy", IOSR Journal of Business and Management (IOSR-JBM) ISSN: 2319-7668. Volume 19, Issue 10. (2017), PP 26-30

[4] Gupta, 'GST- impact on common man', Financial Express, 29 $9^{\text {th }}$ March 2017.

[5] R. Swathi and Siranjeevi, Impact of Goods and Service Tax On Warehousing Industry In India. International Journal of Management, 8 (5), 2017, pp. 111-115.

[6] Nitin Kumar, "Goods and Service Tax in India-A Way Forward", "Global Journal of Multidisciplinary Studies”, Vol 3, Issue6, 2014.

[7] Prof.Pooja.S.Kawle and Prof.Yogesh.L.Aher, 'GST: An economic overview: Challenges and Impact ahead', International Research Journal of Engineering and Technology, Volume: 04, Issue: 04, 2017, pp 2760-2762.

[8] Gurveen Kaur, GST in India - A significant Tax Amendment. International Journal of Management, 8 (3), 2017, pp. 53-62.

[9] Shafie Mohamed Zabri , "Understanding of Goods and Services Tax (GST) and Spending Behavior among Malaysian Consumers" Prosiding Persidangan Kebangsaan Ekonomi Malaysia Ke-11 2016, 2016

[10] Shefali Dani S, “A Research Paper on an Impact of Goods and Service Tax (GST) on Indian Economy”, Business Economic Journal, volume 7, 2016

[11] Aswathy Ashok and Dr. Ranjith Kumar S, A Study on Impact of Gst on Miscellaneous Industry; Gold, International Journal of Mechanical Engineering and Technology, 9(11), 2018, pp. 608-613.

[12] Subhamoy Banik and Arundhuti Das, 'GST in India: Impact and challenges' IOSR Journal of Business and Management, Volume 19, Issue 12, 2017, PP 07-10. 